Jurnal Bimas Islam Vol 14 No. 2

Website: jurnalbimasislam.kemenag.go.id/index.php/jbi

ISSN 2657-1188 (online) ISSN 1978-9009 (print)

\title{
E-Filantropi Pembiayaan Pendidikan: Gerakan Altruisme dalam Pemberdayaan Masyarakat Perbatasan di Tengah Pandemi Covid-19
}

\section{E-Philanthropy in Education Financing: Altruism Movement in Empowering Border Communities amidst the Covid-19 Pandemic}

\author{
Wildani Hefni \\ Universitas Islam Negeri (UIN) Kiai Haji Achmad Siddiq Jember \\ email: wildani91@gmail.com
}

Artikel diterima 13 September 2021, diseleksi 20 September 2021 dan disetujui 20 Desember 2021

Abstrak: Artikel ini mengkaji pola baru kerja kemanusiaan yang dijalankan dalam dunia teknologi, diistilahkan dengan e-filantropi. Penggunaan ruangruang digital dengan menggunakan platform donasi online menjadi konsep e-filantropi yang menjadi pilihan di tengah pandemi covid-19 yang menerjang seluruh lapisan masyarakat. Studi ini menggunakan pendekatan kualitatif deskriptif dengan metode etnografi virtual. Objek studi ini adalah program \#beasiswaArjuna Pondok Pendawa, Bogor yang meneguhkah gerakan altruisme dengan membuka donasi secara online untuk pembiayaan pendidikan bagi masyarakat perbatasan. Artikel ini menunjukkan bahwa filantropi mengalami pergeseran dari bentuk konvensional menuju digital, utamanya di masa pandemi covid-19. E-filantropi menjadi pilihan dari gerakan altruisme dalam memperkuat solidaritas kemanusiaan dengan meninggalkan semua keegoisan dan membantu masyarakat perbatasan untuk mengenyam dunia pendidikan. Praktik filantropi dalam gerakan altruisme di tengah pandemi covid-19 menginspirasi setiap orang untuk terlibat dalam tindakan altruistik dalam rangka mewujudkan kebahagian bagi semua orang. 
Kata Kunci: E-Filantropi, Pembiayaan Pendidikan, Pemberdayaan Masyarakat, Altruisme, Covid-19

Abstract: This article examines a new pattern of humanitarianism through digital technology, known as e-philanthropy. The utilization of digital space with social media has become an e-philanthropy concept amidst the covid-19 pandemic that happened to all levels of society. This study is qualitative descriptive with virtual ethnographic methods. The object of this research is program of \#beasiswaArjuna, Pondok Pendawa, Bogor that implemented the altruism movement by collecting online donations to finance education for border communities. This article shows that philanthropy has shifted from conventional to digital forms, especially amidst the covid-19 pandemic. E-philanthropy manifests as an altruism movement in strengthening humanitarian solidarity by eliminating all selfishness and helping border communities to continue their education. The practice of philanthropy in the altruism movement amidst the covid-19 pandemic calls everyone to engage in altruistic actions to create happiness for people.

Keywords: E-Philanthropy, Education Financing, Community Empowerment, Altruism, Covid-19

\section{A. Pendahuluan}

Pandemi covid-19 yang melanda Indonesia memberikan dampak yang cukup signifikan terhadap kehidupan masyarakat. Tidak hanya kehidupan sosial, namun juga politik, ekonomi, budaya, dan dunia pendidikan juga menerima imbas dari pandemi yang terus mengubah cara kerja, cara berinteraksi, dan cara beraktivitas. ${ }^{1}$ Pola kehidupan tidak lagi berjalan sebagaimana biasanya, namun telah bergeser ke arah dunia teknologi. ${ }^{2}$ Kebutuhan terhadap ruang digital tidak hanya berhenti pada kebutuhan individu dalam menjalani kehidupan sehari-hari, namun menjadi kebutuhan kelembagaan dalam melangsungkan kerja-kerja kemanusiaan. 
Dunia digital menjadi pilihan paling rasional di saat semua orang harus bekerja dan beraktivitas dari rumah. Pada tingkat sosialbudaya, terjadi sebuah transformasi besar masyarakat global sebagai akibat dari pandemi yang tak kunjung hilang dari muka bumi. ${ }^{3}$ Yasraf Amir Piliang menyebut bahwa perkembangan teknologi informasi telah mencipta sebuah ruang berskala global yang disebut cyberspace. ${ }^{4}$ Dalam ruang cyberspace, lahir secara terstruktur sebuah komunitas global yang disatukan oleh ruang dan interaksi digital (virtual community). Yang nampak adalah realitas baru berbentuk dunia visual dalam rangka menghilangkan hambatan ruang dalam percepatan dunia kehidupan. ${ }^{5}$ Ruang virtual inilah yang menjadi pilihan satu-satunya yang memungkinkan untuk terus melakukan aktifitas, menyelesaikan tanggung-jawab, menunaikan amanah, dan menjaga ritme produktivitas di tengah turbulensi kehidupan.

Pilihan pada dunia kecepatan melalui ruang digital teknologiinformasi, menjadi pilihan demi keberlangsungan dunia kerja, bisnis, termasukjuga dunia pendidikan. Yang dibutuhkan adalah keterhubungan dan keberlangsungan aktifitas. Bahkan, pola kedermawanan sebagai bagian dari kerja kemanusiaan untuk membantu dan meringankan beban, beralih pada dunia teknologi.

Artikel ini mengkaji pola baru kerja kemanusiaan sebagai bagian dari aksi filantropi yang diwujudkan dalam dunia teknologi, yang kemudian dikenal dengan e-filantropi. Rahmawati menyebut, E-filantropi ditandai dengan terjadinya pergeseran dalam penyemaian solidaritas sosial dari sistem konvensional menjadi sistem virtual dengan memanfaatkan ruang digital. ${ }^{6}$ Selain meningkatkan akuntabilitas dalam penyaluran bantuan atau donasi, filantropi yang merupakan bagian dari altruisme sosial, menjadi sangat terbantu dengan pemanfaatan teknologiinformasi. Ruang digital menjadi pilihan untuk semakin mendekatientitas donor untuk menyalurkan donasi. ${ }^{7}$ Menurut Rahmawati, kecepatan dalam beradaptasi dengan perubahan dan dinamika kehidupan sosial menjadi poin penting dalam pengelolaan lembaga filantropi. ${ }^{8}$ Mekanisme pilar 
filantropi yang meliputi fundraising, pengelolaan, distribusi, evaluasi, dan sustainability semakin mudah untuk dikontrol.

Dalam dunia pendidikan, donasi-donasi dari para donatur dapat dialihkan dalam satu sistem yang terintegrasi. Seperti halnya di Pondok Pesantren Entrepreneurship Pemuda dan Mahasiswa (Pendawa), Parung Bogor. Di pesantren ini, wujud kedermawanan diejewantahkan dengan pemberian beasiswa kepada masyarakat perbatasan, yang dalam hal ini adalah santri dari pesantren perbatasan yang meliputi daerah $3 \mathrm{~T}$ (terdepan, terpencil, dan tertinggal) pada wilayah Indonesia. Gerakan filantropi yang diwujudkan dalam aksi altruisme dijalankan melalui platform digital dalam bentuk donasi yang bertujuan untuk membantu masyarakat pesantren di perbatasan agar tetap mampu mengenyam pendidikan. Dengan bahasa yang sederhana, pesantren Pendawa ini mempraktikkan e-filantropi dalam pembiayaan pendidikan sebagai wujud dari gerakan altruisme, utamanya di tengah pandemi covid-19 yang menyasar seluruh lapisan masyarakat dan menyisakan kebimbangan serta kegamangan hidup.

Pesantren Pendawa nampaknya melihat bahwa beasiswa untuk menempuh pendidikan dapat memberikan pengaruh signifikan bagi peningkatan kualitas masyarakat perbatasan. Dalam praktiknya, Pondok Pendawa memberikan perhatian lebih terhadap pengembangan dan pemberdayaan kader pesantren di daerah perbatasan. Perhatian tersebut diwujudkan dengan pemberian beasiswa bagi santri yang memiliki kemampuan akademik, kematangan pribadi, kemampuan penalaran, dan potensi untuk dapat mengikuti program pendidikan Islam sekaligus menyelesaikan pendidikan sarjana dan Magister.

Dalam konteks itu, e-filantropi yang dijalankan di Pesantren Pendawa menemukan relevansinya untuk memberdayakan masyarakat perbatasan dengan tujuan ikut andil dalam peningkatan kualitas sumber daya manusia. Gerakan pemberdayaan tidak berhenti dengan aksi dan aktivitas konvensional-tradisional, melainkan dengan memanfaatkan 
kecanggihan teknologi dalam menerima donasi dari para penggerak filantropi yang memiliki kepedulian terhadap kesejahteraan masyarakat, terutama di saat pandemi covid-19. Pertanyaannya, seperti apa gambaran e-filantropi dalam pembiayaan pendidikan masyarakat (santri) perbatasan di Pesantren Pendawa?. Mengapa pola e-filantoropi dengan memanfaatkan ruang digital untuk donasi menjadi pilihan di tengah pendemi covid-19? Bagaimana gerakan altruisme menjadi penopang terhadap keberlangsungan e-filantropi di pesantren Pendawa ini, khususnya saat pandemi covid-19?.

Artikel ini menggunakan pendekatan kualitatif deskriptif dengan metode etnografi virtual. Pengumpulan data dilakukan dengan dua cara yaitu online dan offline. Secara online dengan mengamati kampanye sosial dan artefak pada website https://beasiswaarjuna.com/ dan media sosial @beasiswaarjuna. Sementara secara offline dengan wawancara, observasi, dan dokumentasi. Pendekatan kualitatif deskriptif bertujuan untuk mengkonstruksi pola e-filantropi dalam pembiayaan pendidikan Islam dalam gerakan altruisme bagi masyarakat perbatasan. Sumber data sekunder berupa buku, artikel jurnal, serta dokumen dan materi-materi yang berkaitan dengan kajian penelitian ini. Semua data yang diperoleh dari hasil observasi, wawancara dan dokumentasi kemudian dianalisis dengan metode kualitatif untuk memperoleh gambaran yang mendalam dengan mengambil hal-hal yang khusus kemudian diambil kesimpulan secara umum.

\section{B. Pembahasan dan Hasil}

Upaya peningkatan kualitas sumber daya manusia menjadi program prioritas pemerintah pada segala aspek kehidupan, baik itu sosial, budaya, politik, dan ekonomi, termasuk dalam sektor pendidikan. Pendidikan menjadi instrumen penting dalam rangka mendorong sumber daya manusia, termasuk didalamnya para santri, untuk menjadi kader handal yang memiliki kecakapan hidup dan skills yang mempuni di tengah kemajuan teknologi dan informasi. Di satu sisi, pandemi 
covid-19 juga telah membawa pada perubahan kehidupan untuk lebih akrab lagi dengan perangkat teknologi.

Sebelum masuk pada pembahasan e-filantropi dan gerakan altruisme, pada awal artikel ini akan dijelaskan potret kelembagaan Pesantren Pendawa yang melangsungkan praktif e-filantropi dalam kedermawanan membiayai pendidikan bagi masyarakat (santri) perbatasan di wilayah tertinggal dan terluar di Indonesia.

\section{Pemberdayaan Masyarakat Perbatasan: Profil Kelembagaan Pesantren Pendawa dan Beasiswa Arjuna}

Pondok Pesantren Entrepreneurship Pemuda dan Mahasiswa, yang disingkat dan dikenal dengan Pesantren Pendawa, terletak di Kampung Hambulu, Desa Pondok Udik, RT 02 RW 07, Kecamatan Kemang, Kabupaten Bogor-Jawa Barat. Pesantren ini didirikan pada tahun 2008 dengan visi menjadi pusat penempaan keagamaan, keilmuan, dan keahlian bagi pemuda dan alumni pondok pesantren. Adapun tujuan utama dari Pondok ini untuk menyiapkan pemuda dan alumni pesantren menjadi bintang dan profesional dengan melayani keragaman kecerdasan, baik kecerdasan sosial, maupun kecerdasan spiritual, dan kemudian dicetak menjadi kaum intelektual yang memiliki kecakapan yang unggul menguasai pemahaman keagamaan dan pemahaman kebangsaan. Falsafah dari Pesantren ini meliputi trilogi nilai yaitu belajar, bekerja, dan beribadah. Sedangkan kompetensi anak didiknya diharapkan paripurna dalam bidang keagamaan, profesional dalam bidang keahlian, dan kreatif untuk menciptakan perubahan. ${ }^{9}$

Secara konsisten, pesantren Pendawa memberikan peluang beasiswa sarjana (S1) (selama 4 tahun) bagi pemuda lulusan setingkat Sekolah Menengah Atas (SMA). Tidak hanya sebagai lulusan SMA, mereka tercatat sebagai alumni pesantren-pesantren yang berasal dari kawasan 3T (Tertinggal, Terdepan, dan Terluar). Pesantren ini lebih mengutamakan para anak didik dari daerah perbatasan negara, dan daerah-daerah terpencil lainnya di Indonesia. Pondok Pendawa saat ini 
telah mencetak sekitar sembilan puluh (90) sarjana dan magister berasal dari berbagai daerah, diantaranya Aceh, Banten, Lampung, Kalimantan Barat, Kalimantan Utara, Kalimantan Selatan, Kalimantan Timur, Nusa Tenggara Timur, Jawa Tengah, Jawa Timur, Sulawesi dan Papua. Mereka telah menyelesaikan studi S1 dan S2 di perguruan tinggi seperti Institut Teknologi Indonesia (ITI) Serpong, Universitas Nahdlatul Ulama Indonesia (UNUSIA), Universitas Pamulang, Universitas Ibnu Khaldun Bogor, Universitas Islam Negeri Syarif Hidayatullah Jakarta dan Institut Pertanian Bogor. ${ }^{10}$

Selain mengenyam pendidikan sarjana, mereka juga dibekali keterampilan (soft skill), misalnya pelatihan budidaya ikan, menjahit, pertanian, wirausaha, pelatihan bahasa asing dan lain-lain. Menurut pendiri Pondok Pendawa, Imam Safei, beasiswa Arjuna berupaya untuk mewadahi saluran donasi masyarakat untuk membantu biaya pendidikan anak-anak rantau yang berasal dari daerah 3T (Tertinggal, Terdepan, dan Terluar). Menurutnya, beasiswa Arjuna diperuntukkan bagi anak-anak Indonesia yang kurang mampu secara ekonomi, yang terbatas akses pendidikan dan anak-anak lain yang kurang beruntung dari daerah-daerah perbatasan. Melalui program tersebut, anakanak yang dari daerah 3T diharapkan mampu untuk mewujudkan keinginan melanjutkan jenjang pendidikan di perguruan tinggi melalui donasi yang diberikan oleh masyarakat. ${ }^{11}$ Dalam konstruksi tersebut, Pondok Pendawa memanfaatkan ruang digital yang disediakan agar memudahkan para donatur memberikan atau menyumbangkan dana bagi pembiayaan pendidikan para santri.

Dalam konteks itu, program beasiswa Arjuna yang digagas sejak tahun 2020 oleh Pesantren Pendawa memberikan peluang yang lebih luas bagi masyarakat perbatasan, yang dalam hal ini adalah para santri di wilayah perbatasan Indonesia, untuk mengembangkan minat bakat serta menggapai mimpi-mimpi mereka tentang pendidikan. Satu hal yang menjadi pijakan dasar dari tujuan program ini adalah tumbuhnya kader bangsa yang kokoh dan tangguh secara keimanan dan ketaqwaan 
sekaligus kuat dalam penguasaan ilmu pengetahuan dan teknologi. Para santri dibekali dengan proses penggodokan dalam aspek religiusitas secara berkala dan berkesinambungan selama berada di pesantren. Hasil yang diharapkan tentunya adalah bahwa mereka mempunyai kualitas keimanan yang kokoh sebagai salah satu fondasi yang amat fundamental bagi generasi bangsa.

Pelaksanaan program ini menandakan adanya perhatian terhadap anak bangsa. Ada sikap altruisme yang tumbuh dan kemudian meluas dengan disediakan ruang-ruang berbagi. Program ini menjadi sebuah program yang cerdas dan taktis dalam rangka meningkatkan kecerdasan anak bangsa lewat pemberdayaan kaum santri. Program ini secara mendasar mengandung beberapa kepedulian yang cukup tinggi terhadap anak bangsa, yang secara khusus kader santri pondok pesantren yang berada di lingkungan masyarakat pedesaan dan tergolong berekonomi lemah. Para santri sebagian besar juga berasal dari keluarga yang kurang mampu.

Dengan demikian, pemberdayaan masyarakat perbatasan, yang dalam hal ini adalah kader pesantren melalui pembiayaan pendidikan, memiliki tiga tujuan utama. Pertama, memperluas akses bagi santri untuk mendorong kematangan pribadi, kemampuan penalaran, dan prestasi untuk memperoleh pendidikan tinggi. Tidak sedikit para kader pesantren perbatasan yang mempunyai kemampuan luar biasa, kecerdasan yang imajiner, namun mereka terhalang untuk melanjutkan pendidikan, terutama pada level perguruan tinggi. Program pembiayaan pendidikan melalui beasiswa Arjuna ini hendak mengantar para santri untuk menggapai cita-cita tinggi yaitu menempuh pendidikan di perguruan tinggi tanpa mengeluarkan biaya.

Kedua, meningkatkan kualitas Sumber Daya Manusia (SDM) Indonesia di bidang sains, teknologi serta sosial kemasyarakatan agar dapat mengoptimalkan peran pembangunan dimasa mendatang. Banyak pondok pesantren yang mengalami kendala karena minimnya 
jangkauan akses. Pesantren kekurangan SDM dalam beberapa hal utamanya saat dihadapkan dengan kemajuan zaman. Misalnya, dalam bidang teknologi informasi, sains, dan lain sebagainya. Dengan adanya program ini, diharapkan akan tumbuh generasi pesantren yang melek tekhnologi informasi dan tidak ketinggalan zaman. Ketiga, memperkuat jaringan kerjasama (network) antara dunia pendidikan tinggi dengan pondok pesantren dalam upaya memperkuat pesantren sebagai lembaga pendidikan, dakwah dan pengembangan masyarakat.

Tiga faktor itulah yang menjadi tujuan utama Pondok Pendawa dalam memberikan pendidikan dan pengajaran untuk para santri. Visi utama tidak lain kecuali untuk melayani keragaman kecerdasan dalam rangka mencetak para kader bangsa untuk mendapatkan bekal hidup yang dapat dilaksanakan di tengah-tengah masyarakat.

\section{E-Filantropi: Pergeseran dari Filantropi Konvensional ke Digital}

Secara etimologis, makna filantropi adalah kedermawanan, kemurahatian, sumbangan sosial, atau sesuatu yang menunjukkan cinta kasih kepada manusia. ${ }^{12}$ Dalam konsep filantropi, yang dibangun adalah sebuah tujuan untuk meningkatkan rasa dan nilai kemanusiaan dengan cinta pada sesama. Karena itu, praktik filantropi merupakan kerja yang sifatnya giving, services, yang dilakukan secara sukarela. ${ }^{13}$ Zaenal Abidin (2012) mengungkapkan bahwa filantropi merupakan voluntary action for the public good, sebuah tindakan sukarela untuk kepentingan publik. ${ }^{14}$ Kata filantropi berasal dari bahasa Yunani, yaitu philos yang berarti cinta (love) dan anthropos yang berarti manusia (human kind), sehingga kata philantrophy dimaknai sebagai ungkapan cinta kasih kepada sesama manusia. ${ }^{15}$ Dalam bahasa agama, konsep filantropi seringkali disamakan dengan konsep al-a'ta al-ijtima'i yang artinya pemberian sosial, al-takaful al-insani yang berarti solidaritas kemanusiaan. ${ }^{16}$ Filantropi juga memiliki makna yang lebih dekat dengan istilah charity, yaitu cinta yang tak bersyarat (unconditioned love). ${ }^{17}$ 
Dalam perkembangannya, konsep filantropi memiliki beberapa tujuan, yang diantaranya adalah bergerak dalam perubahan sosial dengan menjadikan keadilan sosial sebagai tujuan utamanya. ${ }^{18}$ Dengan bahasa yang sederhana, praktik filantropi sejatinya untuk menjawab permasalahan publik yang ada di tengah-tengah masyarakat dengan ciri program yang berkelanjutan, bergerak di ranah makro, menyelesaikan permasalahan di tingkat struktur dan mengubah sistem. ${ }^{19}$

Perkembangan kehidupan yang setiap hari mengalami perubahan dan kemajuan, yang ditandai dengan munculnya pelbagai media baru dalam ruang digital, kemudian menjadi kanal pilihan dalam kegiatan filantropi. Selain ditopang oleh kemajuan zaman dengan perkembangan dunia teknologi-informasi, pilihan kepada media online menjadi satusatunya alternatif keberlangsungan gerak aktivitas di masa pandemi covid-19. Maka, dua faktor besar itulah, yang kemudian mengubah pola praktik filantropi dengan memanfaatkan media digital dari kecanggihan teknologi-informasi. Hal itulah yang kemudian dikenal dengan istilah e-filantropi. ${ }^{20}$

Memasuki era 4.0, pemanfaatan teknologi digital kian masif dan berkembang, yang ditandai dengan maraknya platform online di layanan jasa keuangan (financial technology). Di luar tren layanan financial technology, kegiatan pengumpulan dana masyarakat untuk sosial (filantropi) secara online juga menjadi hal yang lumrah, dan menjadi pilihan di tengah pandemi covid-19. Secara sederhana, dapat disimpulkan bahwa dunia digital sudah menjadi gaya hidup, termasuk untuk kebutuhan spiritual. Dalam konteks inilah, terdapat peluang bagi lembaga filantropi untuk up-to-date dengan menyesuaikan dengan perkembangan kemajuan zaman.

Realisasi praktik filantropi dengan memanfaatkan teknologi era digital berkontribusi pada pola pengumpulan dan pengelolaan filantropi yang akuntabel. Melalui urun dana atau istilah lain crowdfunding yang diintegrasikan dengan kemampuan digital internet, praktik 
penggalangan dan pengelolaan dana akan semakin besar. ${ }^{21}$ Realitas demikian terus menjamur sejalan dengan tren digital yang saat ini sangat digeluti terutama oleh generasi milenial yang kemudian menjadi gaya hidup masyarakat Indonesia. Hal itu bisa dilihat mulai dari hal-ihwal belanja kebutuhan sehari-hari, hingga juga termasuk dalam membantu pekerjaan orang lain, dan memberikan rasa kepedulian terhadap sesama. Semuanya dilakukan lewat laptop atau smartphone dengan memanfaatkan dunia gital.

Pesatnya pertumbuhan penggalangan dana melalui ruang digital antara lain didorong tren digital di kalangan generasi $\mathrm{Y}$ atau generasi milenial Indonesia. Ini akan semakin besar dan massif lantaran dibarengi dengan lahirnya generasi belanja online, yang didorong dengan masifnya situs belanja online (e-commerce). ${ }^{22}$ Secara logika, generasi belanja online akan melakukan donasi juga secara online. Maka, secara natural potensi penggalangan dana publik baik untuk tujuan sosial maupun usaha (crowdfunding) memiliki ruang yang lebih besar. Hal ini juga terjadi pada pemberian donasi pada aspek peningkatan pendidikan dan pemberdayaan masyarakat melalui donasi beasiswa.

Donasi beasiswa Arjuna di Pondok Pendawa dengan pemanfaatan dunia digital menjadi gambaran bahwa praktik filantropi telah mengalami pergeseran dari cara konvensional ke media digital. Beberapa faktor yang menyebabkan, antara lain pandemi covid-19 yang membatasi aktivitas manusia, kemudahan berdonasi, adanya kepercayaan yang lebih besar dari donatur karena sangat transparan dan akuntabel. Semua faktor ini menjadi indikator bahwa e-filantropi menjadi pilihan dari gerakan altruisme dalam mewujudkan dan memperkuat solidaritas kemanusiaan dengan membantu dan meringankan beban, yang dalam hal ini adalah beban masyarakat perbatasan (santri) dalam mengenyam dunia pendidikan. 


\section{E-Filantropi melalui Donasi Beasiswa Arjuna}

Gerakan altruisme dengan memberdayakan para kader pesantren yang diwujudkan dengan pemberian beasiswa melalui ruang digital dengan program bernama Beasiswa Arjuna (Anak Rantau Menjadi Ulama dan Sarjana). Program ini dirancang dalam latar penciptaan sebuah kesadaran ideologis yang memberikan landasan kuat untuk proses transformasi sosial yang fundamental untuk melahirkan kaum intelektual yang berwawasan luas dengan landasan spiritual yang kuat.

Ada ribuan dan bahkan jutaan para santri di nusantara yang memiliki kecerdasan luar biasa, memiliki prestasi yang menggunung dan motivasi serta etika yang membanggakan, termasuk mereka yang berada di wilayah perbatasan Indonesia dengan negara lain yang masih merasakan keterbatasan, terutama dalam sarana pendidikan. Para santri di perbatasan ini memiliki kreatifitas dan inovasi, bahkan visioner yang siap menjadi pionir dibidangnya masing-masing. Para santri mengharapkan pendidikan yang dapat memberdayakan mereka pada masa depan sekaligus merealisasikan harapan dan mimpi-mimpinya tentang pendidikan.

Beasiswa Arjuna merupakan salah satu alternatif program pembiayaan pendidikan melalui donasi yang diperuntukkan bagi santri dan siswa di wilayah perbatasan dan tertinggal. Program ini memberikan akses pendidikan bagi mereka yang dalam kategori miskin, berprestasi dan memiliki kemauan yang kuat untuk menyelesaikan jenjang pendidikan sarjana. Melalui tagar \#YukBantuParaArjuna pada kanal website beasiswaarjuna.com, Pondok Pendawa menggalang dana dengan didasari oleh semangat gerakan altruisme (Gambar 1). Hasil donasi yang diperoleh dari para donator, kemudian dikelola oleh Pesantren untuk digunakan dalam pembiayaan pendidikan masyarakat (santri) perbatasan, baik itu untuk uang makan, operasional pesantren, dan biaya pendidikan baik di tingkat sarjana maupun tingkat Magister. Para donatur dari daerah mana saja, baik di Indonesia maupun di luar 
negeri, dengan mudah dapat mendonasikan dana melalui aplikasi yang tersedia pada website beasiswaarjuna.com.

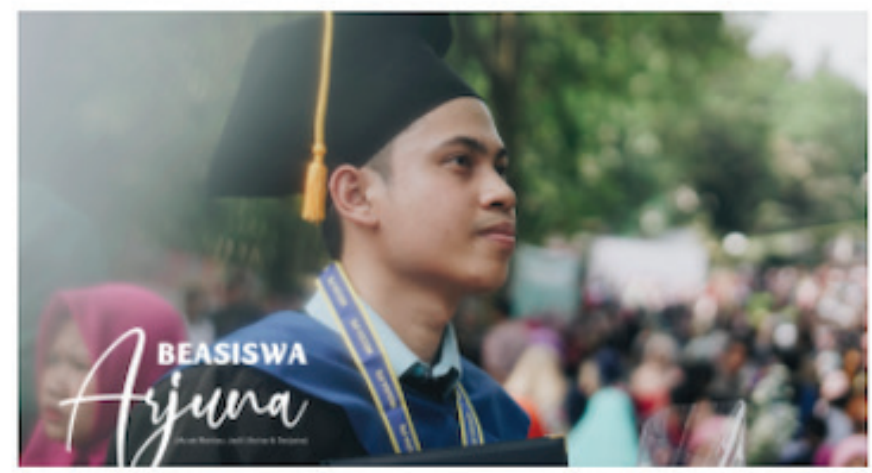

\section{\#YukBantuParaArjuna}

Mari Lakukan Bersama - sama

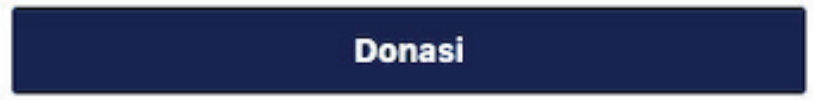

Gambar 1. Tagar \#YukBantuParaArjuna yang digunakan sebagai kampanye menggaet para donatur

Pondok Pendawa menggunakan aplikasi online sehingga dengan mudah untuk disosialisasikan dan dikampanyekan ke publik secara luas. Selain itu, transparansi juga menjadi bagian dari cara untuk membangun kepercayaan (trust) kepada masyarakat umum, terutama kepada donatur. Menurut penuturan Miftahul Abshor, santri senior Pondok Pendawa yang diberikan amanah untuk mengurus program ini, penggunaan dana dari donatur akan dipertanggungjawabkan secara tertulis kepada para donatur. ${ }^{23}$ Selain itu, jumlah donasi ditampikan dalam website beasiswaajurna.com dan bisa dicek secara real-time (Gambar 2). Tampilan website juga beasiswaarjuna dikemas secara simpel, dilengkapi petunjuk atau cara berdonasi, sehingga memudahkan para donatur untuk berpartisipasi. Dengan hanya mengklik menu \#Donasi, maka proses transfer uang dapat dilakukan dalam hitungan waktu yang sangat cepat (Gambar 3). 


\section{Tentang Beasiswa Arjuna}

Beasiswa Arjuna merupakan salah satu alternatif program pembiayaan pendidikan melalui donasi yang diperuntukkan bagi santri dan siswa di wilayah perbatasan dan tertinggal. Program ini memberikan akses pendidikan bagi mereka yang dalam kategori miskin, berprestasi dan memiliki kemauan yang kuat untuk menyelesaikan jenjang pendidikan sarjana. Beasiswa Arjuna telah menghasilkan 90 Sarjana dan Magister yang bermitra di 4 Perguruan Tinggi dan 53 Pondok Pesantren di seluruh wilayah Indonesia.

\section{Lulusan}

\section{Mitra Program}

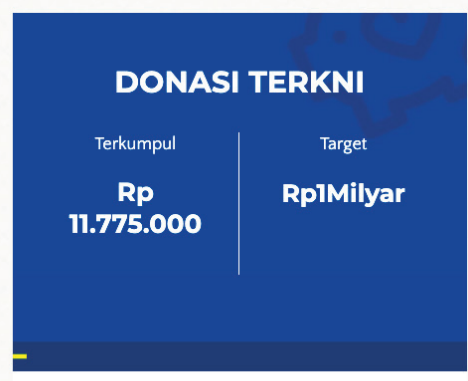

Beasiswa Arjuna

Gambar 2.

Tampilan jumlah donasi yang terkumpul

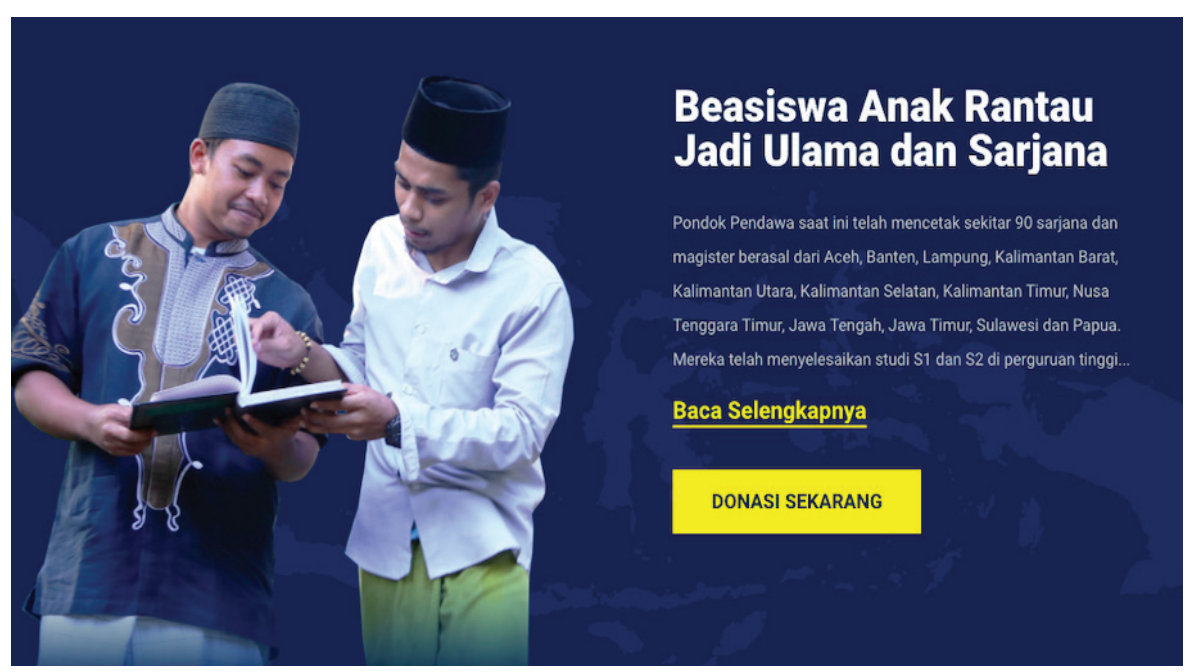

Gambar 3. Tampilan website beasiswaarjuna.com

Menurut penuturan Miftahul Abshor, santri senior Pondok Pendawa yang diberikan amanah untuk mengurus program ini, penggunaan aplikasi online dalam e-filantropi pembiayaan pendidikan di Pondok Pendawa dimaksudkan untuk mematahkan stigma negatif yang selama ini melekat dalam aktivitas donasi konvensional. Dalam donasi konvensional, rentang terjadinya manipulasi dan penyalahgunaan dana donasi, misalnya donasi bodong, malpraktik, dan lainnya. ${ }^{24}$ 
Dengan demikian, beasisiswa Arjuna diberikan kepada para santri melalui aktivitas galang dana dengan strategi dan cara-cara tertentu, yang salah satunya dengan memperbanyak konten di media sosial. Beasiswa Arjuna menjadi produk tertentu sebagai perwujudan dari gerakan altruisme yang dikemas dalam penggalangan dana melalui donasi dengan memanfaatkan kecanggihanan teknologi informasi yaitu platform digital berbasis internet.

\section{Konsep E-Filantropi: Gerakan Altruisme dan Solidaritas Sosial Kemanusiaan}

Kata altruisme pertama kali dimunculkan pada abad ke-19 oleh Auguste Comte. Comte mengartikan altruisme dengan living for others, yang dalam bahasa Perancis ditulis vivre pour autrui. Sebagaimana yang diungkap Robertus Robet, altruisme ditengarai berasal dari bahasa Perancis, autrui, bahasa yang digunakan Comte. ${ }^{25}$ Merujuk pada kutipan yang ditulis Robet, Comte menulis, sebagaimana dikutip dari Campbell, sebagai berikut:"... It follows that happiness and worth, as well in individuals as in societies, depend on adequate ascendancy of the sympathetic instincts. Thus the expression, living for others, is the simplest summary of the whole moral code of positivism (Kebahagiaan dan nilai, baik dalam individu maupun dalam masyarakat, bergantung pada dorongan naluri simpatik yang memadai. Jadi ungkapan bahwa hidup untuk orang lain adalah ringkasan paling sederhana dari keseluruhan jangkar moral positivisme). ${ }^{26}$

Dalam Kamus Besar Bahasa Indonesia (KBBI), altruisme memiliki arti paham (sifat) yang lebih memperhatikan dan mengutamakan kepentingan orang lain, atau sikap yang ada pada manusia, yang mungkin bersifat naluri, berupa dorongan untuk berbuat jasa kepada orang lain. ${ }^{27}$ Dalam analisis Comte, seseorang memiliki tanggung jawab moral untuk melayani umat manusia sepenuhnya. Secara konseptual, altruisme merupakan bentuk perhatian yang tidak mementingkan diri sendiri, melainkan perhatian lebih kepada orang lain sebagai maksud untuk memberikan bantuan. Ada tiga komponen penting dalam altruisme, 
yaitu loving others, helping them doing their time of need, and making sure that they are appreciated (mencintai orang lain, membantu orang lain saat dibutuhkan, dan memastikan bahwa orang lain dihargai). ${ }^{28}$

Adapun aspek-aspek perilaku altruistime terdiri atas lima hal, yaitu: empati, meyakini keadilan dunia, tanggung jawab sosial, kontrol diri internal, dan ego yang rendah. Faktor-faktor yang memengaruhi perilaku altruisme, antara lain suasana hati, empati, meyakini keadilan dunia, faktor sosio-biologis, dan faktor situasional. ${ }^{29}$ Seseorang yang altruis memiliki motivasi altruistik, sebuah keinginan untuk selalu menolong orang lain dan hal itu lahir dari faktor keinginan pribadi. Dengan bahasa yang sederhana, altruisme memiliki motivasi yang tinggi untuk membantu dan meningkatkan kesejahteraan serta kebahagiaan orang lain. ${ }^{30}$

Sementara solidaritas sosial-kemanusiaan bergerak secara dinamis dan tak dapat dikekang oleh mekanisme organis. Solidaritas sosial justru muncul dalam sebuah komunitas sebagai kekuatan jejaring untuk mengimbangi nilai-nilai modernitas yang mulai mengikis fondasi dasar kebersamaan dan kekompakan. ${ }^{31}$ Dalam ikatan solidaritas sosial, terdapat sebuah komitmen yang dipagari oleh rasa kemauan yang lahir dari faktor internal kemauannya sendiri. Dalam konteks altruisme, faktor kemauan yang lahir dari kehendaknya sendiri kemudian bertengger dalam solidaritas sosial yang berdiri kokoh dengan tujuan untuk dapat meringankan beban orang lain. Dari solidaritas sosial inilah kemudian menjadi satu ikatan kuat dalam altar komitmen kolektif.

Altruisme sebagai sebuah ide yang mendahulukan kebahagiaan, menolong, melayani, serta berkorban untuk orang lain, pada perkembangannya menjadi sebuah aktifitas dalam bentuk filantropi. Pola kedermawanan ini dalam konteks Indonesia, berkembang dalam manajemen yang profesional dalam hal pengelolaannya, bahkan secara kelembagaan memiliki payung normatif, seperti Badan Amil Zakat Nasional (Baznas) sebagai satu-satunya lembaga amil zakat yang 
dibentuk oleh pemerintah, yang dalam hal ini Kementerian Agama, untuk mengelola peyaluran zakat, infaq dan sodaqoh secara nasional. ${ }^{32}$

Gerakan altruisme di Pondok Pendawa dikembangkan untuk memberdayakan para santri agar memiliki kecakapan yang unggul. Tujuannya utamanya untuk mencetak pemimpin masa depan bangsa. Dalam praktiknya, para santri diberikan pembekalan yang integratif antara pemahaman keagamaan dan pemahaman kebangsaan melalui pelayanan keragaman kecerdasan di Pondok Pendawa. Para santri yang berasal dari daerah perbatasan ini kemudian dapat mengembangkan potensi diri baik itu prestasi akademik, kecerdasan sosial, maupun kecerdasan spiritual.

Dalam konteks memberdayakan para santri dengan sistem pesantren sekaligus menempuh pendidikan sarjana di perguruan tinggi, tentu dibutuhkan biaya. Pondok Pendawa memberikan beasiswa penuh mulai dari tempat tinggal, uang makan, dan bahkan pendidikan sarjana dan Magister. Maka, konsep yang dijalankan adalah penggalangan dana melalui aplikasi platform online. Dengan demikian, konsep e-filantropi menjadi pilihan yang tepat dalam mewujudkan gerakan altruisme dan menguatkan solidaritas kemanusiaan, utamanya di tengah pandemi covid-19. Semua itu memiliki tujuan untuk memberdayakan pendidikan para santri perbatasan agar terus mampu mengenyam dunia pendidikan walaupun dihadapkan dengan situasi serba sulit.

\section{E-Filantropi: Kedermawanan Kontemporer di Tengah Pandemi}

Ruang digital teknologi informasi selalu mengalami perkembangan yang melipat ruang dan waktu sehingga memudahkan segala aktivitas, termasuk aktivitas kemanusiaan berupa pemberian donasi dalam wujud kedermawanan. Di tengah problematika sosial akibat dari pandemi covid-19, ruang gerak aktivitas beralih pada ruang-ruang digital dengan memanfaatkan teknologi informasi. Teknologi informasi menjadi penyangga keberlangsungan hidup, bahkan juga menjadi media dalam 
pengumpulan donasi dalam pembiayaan pendidikan bagi masyarakat perbatasan di wilayah terdepan, tertinggal, dan terpencil di Indonesia.

E-filantropi menjadi pilihan yang paling memungkinkan untuk melangsungkan kegiatan solidaritas kemanusiaan dengan melahirkan teknologi sub-budaya dalam gerak dan altar altruisme Islam dengan pola dan cara kerja yang tidak lagi bersifat konvensional. ${ }^{33}$ Platform digital yang dioperasionalkan oleh lembaga pengumpul dana berfungsi untuk mengecilkan biaya dengan pelbagai kreativitas yang ada. Hal ini menjadi diskursus baru dalam percaturan perkembangan filantropi Islam yang mewujud dalam gerakan altruisme.

Konsep e-filantropi yang dilakukan oleh Pondok Pendawa, menggambarkan bahwa gerakan altruisme sebagai tindakan sukarela untuk membantu orang dengan tanpa mengharap imbalan, berada pada ruang dan tujuan yang sama antara pengelola dana (pihak pesantren) dan pemberi donatur. Para pengelola Pesantren mengejewantahkan gerakan altruisme dalam melayani dan membantu para santri untuk dididik menjadi Ulama dan sarjana unggul, tanpa kemudian berharap imbalan dalam proses belajar mengajar. Pada titik inilah, gerakan altruisme itu dapat dilihat dalam konsepsi tingkah laku yang merefleksikan pertimbangan untuk tidak mementingkan diri sendiri, lembaga, kelompok, namun lebih memperhatikan kepada pihak-pihak lain yang sedang membutuhkan. ${ }^{34}$ Sementara pada donatur, juga menjadi bagian dari gerakan altruisme ditandai dengan adanya empati kemanusiaan untuk merasakan perasaan orang lain sehingga termotivasi untuk membantu dan menyalurkan donasi. ${ }^{35}$

Dari abstraksi di atas, wabah pandemi covid-19 yang menerjang seluruh lapisan masyarakat, sejatinya mengajarkan untuk mempererat solidaritas kemanusiaan dan meninggalkan semua keegoisan. Membantu orang lain dengan sifat kedermawanan dapat menjadi kesadaran yang menggugah baik pada individu maupun secara kolektif. Filantropi dalam konteks ini sejatinya diperlukan untuk meringankan beban orang 
yang sedang membutuhkan. Konsep itu tak terpisahkan dari konsep altruisme sebagai nilai moral tertinggi untuk memastikan kebaikan orang lain. Altruisme adalah cinta tanpa syarat untuk semua orang. Pandemi covid-19 sejatinya memanggil setiap orang untuk terlibat dalam tindakan altruistik dalam rangka mewujudkan kebahagian bagi setiap orang. Matthieu Ricard, seorang ahli teori dan praktisi altruisme, menegaskan bahwa semakin luas lingkaran perawatan dan perhatian terhadap orang lain, maka semakin otentik rasa solidaritas kemanusiaan. ${ }^{36}$ Solidaritas kemanusiaan dapat diwujudkan dengan pemberian dana agar dapat membantu, setidaknya memudahkan orang lain yang sedang berada dalam garis keterbatasan.

Dengan demikian, masa pandemi covid-19 ini dijadikan momen tepat oleh Pondok Pendawa untuk meneguhkan gerakan altruisme yang memandang kesejahteraan dan kebahagiaan dapat ditanggung secara kolektif dengan memberikan pelayanan kepada masyarakat perbatasan. Penyediaan e-filantropi yang diwujudkan dengan pengumpulan dana dalam pembiayaan pendidikan bagi masyarakat perbatasan sejatinya menjadi konsep filantropi dalam wujud altruisme atau kedermawanan kontemporer. Perhatian terhadap kelompok dan orang lain dapat dilakukan dengan memanfaatkan ruang-ruang digital dengan menggunakan platform donasi online sebagai konsep filantropi digital.

\section{Kesimpulan}

Pandemi covid-19 telah mengubah pelbagai pola kehidupan hampir dalam seluruh lini dalam persoalan sosial, budaya, politik, ekonomi, dan pendidikan. Banyak orang mengalami kesusahan akibat pandemi yang terus membatasi aktivitas manusia untuk mencari penghasilan. Angka kemiskinan juga terus bertambah karena efek menurunnya aktivitas ekonomi. Hal ini juga berimbas kepada masyarakat perbatasan yang merasakan kesulitan untuk melanjutkan pendidikan baik itu tingkat sekolah menengah atas maupun di tingkat perguruan tinggi. 
Pondok Pendawa melihat situasi yang serba tidak menentu dalam kegamangan hidup dengan menginisiasi gerakan altruisme melalui penggalangan dana untuk pembiayaan pendidikan bagi masyarakat perbatasan, yang dalam hal ini adalah para santri dari daerah $3 \mathrm{~T}$ yaitu terdepan, tertinggal dan terpencil di wilayah perbatasan negara. Pondok pendawa menggalang dana dengan menginisiasi program Beasiswa Arjuna (Anak Rantau Menjadi Ulama dan Sarjana) dengan memanfaatkan dunia teknologi, yang dikenal dengan e-filantropi. Gerakan donasi dana dimaksudkan sebagai pembiayaan bagi kelangsungan pendidikan para santri.

Donasi beasiswa Arjuna di Pondok Pendawa menjadi gambaran bahwa praktik filantropi telah mengalami pergeseran dari cara konvensional ke media digital. Beberapa faktor yang menyebabkan, antara lain pandemi covid-19 yang membatasi aktivitas manusia, kemudahan berdonasi, adanya kepercayaan yang lebih besar dari donatur karena sangat transparan dan akuntabel. Dalam perjalanannya, realisasi praktik filantropi dengan memanfaatkan teknologi era digital berkontribusi pada pola pengumpulan dan pengelolaan filantropi yang akuntabel.

Konsep e-filantropi menjadi pilihan yang tepat dalam mewujudkan gerakan altruisme dan menguatkan solidaritas kemanusiaan, utamanya di tengah pandemi covid-19. Semua itu memiliki tujuan untuk memberdayakan pendidikan para santri perbatasan agar terus mampu mengenyam dunia pendidikan walaupun dihadapkan dengan situasi serba sulit. Maka, konsep e-filantropi menjadi pilihan untuk mewujudkan keberlangsungan kedermawanan kontemporer di tengah pandemi covid-19 yang dipenuhi dengan turbulensi kehidupan. 


\section{Daftar Pustaka}

Abidin, Zainal. "Manifestasi dan Latensi Lembaga Filantropi Islam dalam Praktik Pemberdayaan Masyarakat: Suatu Studi di Rumah Zakat Kota Malang", Salam: Jurnal Studi Masyarakat Islam, Vol. 15, No. 2 (2012).

Abidin, Zainal. "Paradoks dan Sinjutas (Sinergi-KeberlanjutanKetuntasan Gerakan Filantropi di Indonesia", Share: Social Work Journal, Vol. 6, No. 2 (2016).

Ahmadi, Rizqa dan Wildani Hefni. "Solidaritas Sosial di Era Post-Modern: Sakralitas Komunitas Salawatan Jaljalut Indonesia", Jurnal Lektur Keagamaan, Vol. 17, No. 1 (2019).

Anggraeni, Aisyah Ayu. “Platform Donasi Online dan Filantropi Digital: Kajian Aktivitas Filantropi dan Komodifikasi Kampanye Sosial melalui Kitabisa.com", Thesis, Universitas Airlangga, 2019.

Bahjatulloh, Qi Mangku. “Pengembangan Pemberdayaan Ekonomi Masyarakat Melalui Kegiatan Filantropi (Studi Kasus Lembaga Tazakka DIII Perbankan Syariah IAIN Salatiga)", Inferensi: Jurnal Penelitian Sosial Keagamaan, Vol. 10, No. 2 (2016) https://doi. org/10.18326/infsl3.v10i2.473-494

Batson, C. Daniel. Altruisme In Humans. New York: Oxford University Press, 2011.

Campbell, Robert L. "Altruism in Auguste Comte and AynRand", The Journal of Ayn Rand Studies, Vol. 7, No. 2 (2006).

Efendi, Mansur. "Pengelolaan Filantropi Islam di Tengah Pandemi Covid-19: Studi pada Komunitas Kurir Sedekah", Filantropi: Jurnal Manajemen Zakat dan Wakaf, Vol. 2, No. 1 (2021).

Hefni, Wildani. “Moderasi Beragama dalam Ruang Digital: Studi Pengarusutamaan Moderasi Beragama di Perguruan Tinggi 
Keagamaan Islam Negeri", Jurnal Bimas Islam, Vol. 13, No. 1 (2020). https://doi.org/10.37302/jbi.v13i1.182

Ibrahim, Barbara. From Charity to Social Change: Trends in Arab Philantrophy Cairo: American University in Cairo Press, 2008.

Kamilah, Cahaya dan Neka Erlyani, "Gambaran Altruisme Anggota Komunitas 1000 Guru Kalimantan Selatan”, Jurnal Ecopsy, Vol. 4, No. 1 (2017).

Kharima, Nadya. Fauziah Muslimah, Aninda Dwi Anjani, "Strategi Filantropi Islam berbasis Media Digital", Empati: Jurnal Ilmu Kesejahteraan Sosial, Vol. 10, No. 1 (2021).

Munandar, Siswoyo Aris. "Gerakan Filantropi Jaringan Gusdurian ditengah Wabah Covid-19", Jurnal Bimas Islam, Vol. 14, No. 1 (2021) https://doi.org/10.37302/jbi.v14i1.362

Myers, David G. Social Psychology. New York: McGraw Hill, 2009.

Piliang, Yasraf Amir. Dunia Yang Dilipat: Tamasya Melampaui Batas-Batas Kebudayaan. Bandung: Matahari, 2010.

Piliang, Yasraf Amir. Dunia Yang Berlari: Dromologi, Implosi, Fantasmagoria. Yogyakarta: Cantrik Pustaka, 2017.

Profil Pondok Pendawa, Pendawa: Pesantren Entrepreneurship Pemuda dan Mahasiswa. Bogor: Pondok Pendawa, 2014.

Rahmawati, Yuliana. "E-Filantropi: Studi Media Pergeseran Altruisme Islam Tradisional Menuju Filantropi Online Integratif", Komunika: Jurnal Dakwah dan Komunikasi, Vol. 13, No. 2, (2019).

Robet, Robertus. "Altruisme, Solidaritas, dan Kebijakan Sosial", Jurnal Sosiologi Masyarakat, Vol. 18, No. 1 (2013).

Ricard, Matthieu. Altruism: The Power of Compassion to Change Yourself and the World. New York: Brown and Company, 2015.

Saladiono, Valerio. "The Psychological and Social Impact of Covid-19: 
New Perspectives of Well-Being", Frontiers in Psycology, Vol. 11 (2020).

Saripudin, Udin. "Filantropi Islam dan Pemberdayaan Ekonomi", Bisnis:

Jurnal Bisnis dan Majemejem Islam, Vol. 4, No. 2 (2016) http:// dx.doi.org/10.21043/bisnis.v4i2.2697

Syah Aji, Rizqon Halal. “Dampak Covid-19 pada Pendidikan di Indonesia:

Sekolah, Keterampilan, dan Proses Pembelajaran", Salam: Jurnal Sosial dan Budaya, Vol. 7, No. 5 (2020).

Ubaedillah, Damar Isti Pratiwi, "Utilization of Information Technology during the Covid-19 Pandemic: Student's Perception of Online Lectures", Edukatif: Jurnal Ilmu Pendidikan Vol. 3, No. 2 (2021).

Wawancara dengan Miftahul Abshor, santri senior dan pengelola website beasiswaarjuna, 10 Juni 2021, di Jakarta.

Wawancara dengan Imam Safei, pendiri Pondok Pendawa, 4 Juni 2021 di Jakarta. 


\section{Endnotes}

1. Rizqon Halal Syah Aji, “Dampak Covid-19 pada Pendidikan di Indonesia: Sekolah, Keterampilan, dan Proses Pembelajaran", Salam: Jurnal Sosial dan Budaya, Vol. 7, No. 5 (2020): 396, https://doi.org/10.15408/sjsbs.v7i5.15314 .

2. Valerio Saladino, "The Psychological and Social Impact of Covid-19: New Perspectives of Well-Being", Frontiers in Psycology, Vol. 11 (2020): 2, https://10.3389/fpsyg.2020.577684.

3. Ubaedillah \& Damar Isti Pratiwi, “Utilization of Information Technology during the Covid-19 Pandemic: Student's Perception of Online Lectures", Edukatif: Jurnal Ilmu Pendidikan Vol. 3, No. 2 (2021): 448.

4. Yasraf Amir Piliang, Dunia Yang Dilipat: Tamasya Melampaui Batas-Batas Kebudayaan (Bandung: Matahari, 2011), 24. Baca juga Yasraf Amir Piliang, Dunia Yang Berlari: Dromologi, Implosi, Fantasmagoria (Yogyakarta: Cantrik Pustaka, 2017).

5. Wildani Hefni, "Moderasi Beragama dalam Ruang Digital: Studi Pengarusutamaan Moderasi Beragama di Perguruan Tinggi Keagamaan Islam Negeri", Jurnal Bimas Islam, Vol. 13, No. 1 (2020): 11, https://doi. org/10.37302/jbi.v13i1.182

6. Yuliana Rahmawati, “E-Filantropi: Studi Media Pergeseran Altruisme Islam Tradisional Menuju Filantropi Online Integratif", Komunika: Jurnal Dakwah dan Komunikasi, Vol. 13, No. 2 (2019): 171.

7. Nadya Kharima, Fauziah Muslimah, Aninda Dwi Anjani, “Strategi Filantropi Islam berbasis Media Digital", Empati: Jurnal Ilmu Kesejahteraan Sosial, Vol. 10, No. 1 (2021): 46.

8. Yuliana Rahmawati, “E-Filantropi: Studi Media Pergeseran Altruisme Islam Tradisional Menuju Filantropi Online Integratif, 171.

9. Profil Beasiswa Arjuna diakses pada laman https://beasiswaarjuna.com/ profil/, pada tanggal 2 Juli 2021. Lihat juga Profil Pondok Pendawa: Pesantren Entrepreneurship Pemuda dan Mahasiswa (Bogor: Pondok Pendawa, 2014).

10. Profil Pondok Pendawa: Pesantren Entrepreneurship Pemuda dan Mahasiswa (Bogor: Pondok Pendawa, 2014).

11. Wawancara dengan pendiri Pondok Pendawa, Imam Safei, 4 Juni 2021, di 
Jakarta.

12. Kamus Besar Bahasa Indonesia (KBBI) online, diakses pada laman https:// kbbi.kemdikbud.go.id/entri/filantropi

13. Mansur Efendi, "Pengelolaan Filantropi Islam di Tengah Pandemi Covid-19: Studi pada Komunitas Kurir Sedekah", Filantropi: Jurnal Manajemen Zakat dan Wakaf, Vol. 2, No. 1 (2021): 6.

14. Zainal Abidin, "Manifestasi dan Latensi Lembaga Filantropi Islam dalam Praktik Pemberdayaan Masyarakat: Suatu Studi di Rumah Zakat Kota Malang", Salam: Jurnal Studi Masyarakat Islam, Vol. 15, No. 2 (2012). Lihat pula Zainal Abidin, "Paradoks dan Sinjutas (Sinergi-Keberlanjutan-Ketuntasan Gerakan Filantropi di Indonesia", Share: Social Work Journal, Vol. 6, No. 2 (2016).

15. Qi Mangku Bahjatulloh, "Pengembangan Pemberdayaan Ekonomi Masyarakat Melalui Kegiatan Filantropi (Studi Kasus Lembaga Tazakka DIII Perbankan Syariah IAIN Salatiga)", Inferensi: Jurnal Penelitian Sosial Keagamaan, Vol. 10, No. 2 (2016): 476. https://doi.org/10.18326/infsl3. v10i2.473-494

16. Udin Saripudin, "Filantropi Islam dan Pemberdayaan Ekonomi", Bisnis: Jurnal Bisnis dan Manajemen Islam, Vol. 4, No. 2 (2016): 165. http://dx.doi. org/10.21043/bisnis.v4i2.2697

17. Barbara Ibrahim, From Charity to Social Change: Trends in Arab Philantrophy (Cairo: American University in Cairo Press, 2008).

18. Siswoyo Aris Munandar, "Gerakan Filantropi Jaringan Gusdurian ditengah Wabah Covid-19", Jurnal Bimas Islam, Vol. 14, No. 1 (2021): 35. https://doi. org/10.37302/jbi.v14i1.362

19. Zainal Abidin, "Manifestasi dan Latensi Lembaga Filantropi Islam dalam Praktik Pemberdayaan Masyarakat: Suatu Studi di Rumah Zakat Kota Malang", 2012.

20. Yuliana Rahmawati, “E-Filantropi: Studi Media Pergeseran Altruisme Islam Tradisional Menuju Filantropi Online Integratif", 171.

21. Yuliana Rahmawati, “E-Filantropi: Studi Media Pergeseran Altruisme Islam Tradisional Menuju Filantropi Online Integratif", 172. 
22. Aisyah Ayu Anggraeni, "Platform Donasi Online dan Filantropi Digital: Kajian Aktivitas Filantropi dan Komodifikasi Kampanye Sosial melalui Kitabisa.com", Thesis, Universitas Airlangga, (2019): 5.

23. Wawancara dengan Miftahul Abshor, santri senior dan pengelola website beasiswaarjuna, 10 Juni 2021, di Jakarta.

24. Wawancara dengan Miftahul Abshor, santri senior dan pengelola website beasiswaarjuna, 10 Juni 2021, di Jakarta.

25. Robertus Robet, "Altruisme, Solidaritas, dan Kebijakan Sosial", Jurnal Sosiologi Masyarakat, Vol. 18, No. 1 (2013): 4.

26. Robert L. Campbell, "Altruism in Auguste Comte and AynRand", The Journal of Ayn Rand Studies, Vol. 7, No. 2 (Spring 2006): 360.

27. Kamus Besar Bahasa Indonesia (KBBI) online, diakses pada laman https:// kbbi.kemdikbud.go.id/entri/altruisme.

28. Cahaya Kamilah dan Neka Erlyani, "Gambaran Altruisme Anggota Komunitas 1000 Guru Kalimantan Selatan", Jurnal Ecopsy, Vol. 4, No. 1 (2017): 34.

29. David G. Myers, Social Psychology (New York: McGraw Hill, 2009), 454.

30. C. Daniel Batson, Altruisme In Humans (New York: Oxford University Press, 2011), 56-59.

31. Rizqa Ahmadi dan Wildani Hefni,“ Solidaritas Sosial di Era Post-Modern: Sakralitas Komunitas Salawatan Jaljalut Indonesia", Jurnal Lektur Keagamaan, Vol. 17, No. 1 (2019): 66.

32. Yuliana Rahmawati, "E-Filantropi: Studi Media Pergeseran Altruisme Islam Tradisional Menuju Filantropi Online Integratif", 168.

33. Yuliana Rahmawati, "E-Filantropi: Studi Media Pergeseran Altruisme Islam Tradisional Menuju Filantropi Online Integratif", 170.

34. David G. Myers, Social Psychology, Focus On: The Benefits and the Costs of Empathy-Induced Altruism (New York: McGraw Hill, 2009), 458.

35. David G. Myers, Social Psychology, 457.

36. Matthieu Ricard, Altruism: The Power of Compassion to Change Yourself and the World (New York: Brown and Company, 2015). 